\title{
Emerging Technologies for Food Safety: High Pressure Processing (HPP) and Cold Plasma Technology (CPT) for Decontamination of Foods
}

\author{
Farahnaaz Feroz ${ }^{1}$, Showshan Nafisa ${ }^{1}$ and Rashed Noor ${ }^{2 *}$ \\ ${ }^{I}$ Department of Microbiology, Stamford University Bangladesh, Dhaka; ${ }^{2}$ School of Life Sciences (SLS), Independent University, Bangladesh (IUB), Dhaka, \\ Bangladesh.
}

\begin{abstract}
Foods may become contaminated from a variety of sources, therefore it is imperative to understand and discover easy, cheap and effective means of decontaminating foods. Heat, although effective, economical and easily available, has been reported to produce undesirable effects on food such as loss of taste and nutrition. High Pressure Processing can inactivate the cells of the food borne pathogens and organisms responsible for food spoilage regardless of the temperature without making changes to the texture, color or flavor. Equipment involved in HPP includes a pressure vessel, pumps generating high hydrostatic pressure or intensifiers. Its success depends on certain factors such as pressure of water, temperature used during the treatment, and the properties and state of the food and categories of microorganisms found in food.Cold Plasma Technology (CPT) is a novel, non-thermal food processing technology that uses energetic and reactive gases to inactivate contaminating microorganisms in food products. CPT is environmentally friendly that uses natural gases such as nitrogen, argon, air, hydrogen, and oxygen. Depending on the plasma type, it can inactivate a wide range of microorganisms including food borne pathogens and spoilage organisms. This technology hasa low running cost (Cost of natural gases and electricity).Both HPP and CPT can spread and work on the entire food sample, regardless of shape and size. These methods serve as an alternative to some methods which were previously used.
\end{abstract}

\section{Introduction}

The food and beverage manufacturing industry represents one of the largest manufacturing sectors worldwide.In a consumerdriven market, food processors are constantly challenged to develop food products with consumer-desired characteristics at affordable costs without compromising food safety. Consumers' health and wellness-oriented lifestyles lead to a preference for mildly processed, fresher-tasting foods with minimal or no preservatives.

Food safety management has given priority worldwide in terms of preserving the health and well-being of the society as a whole. Severe and endemic food contamination contributes to economic losses due to medical treatment and legal costs to businesses, loss of productivity, along with the impact on health of the society ${ }^{1,2}$. Foods may be contaminated by pathogenic bacteria, parasitic helminthes, and protozoa ${ }^{2}$. Increased rates of food- borne diseases may also be attributed tofor increased consumption of inadequately processed fruits and vegetables, and eating not homemade foodand interest in eating healthier ${ }^{3}$. There has been a rise in the number of food borne disease cases among elderly and immunocompromized group of people ${ }^{4}$.

Sources of contamination of food include soil, feces, water, fungicides and insecticides, dust, insects, wild and domestic animals and handling during processing ${ }^{3,5}$. The continuous constant changes in the characteristics and behaviour of microorganisms, the food production processes, polluted environment, ecology and trade have resulted in new challenges to maintain food safety, coupled with consumer demands for safer foods ${ }^{6}$. Since there are every possibilities of bacterial and fungal contamination of foods, research necessary to find out appropriate methods of removing or reducing the microbiological loads ${ }^{2,7,8,9}$.

Several studies have assessed conventional, newer techniques and combinations of several methods (hurdle techniques) to control the growth of microbes in foods. Heat control measures are frequently practised, to maintain food safety; theseinclude boiling, cooking, pasteurization, autoclave and heat sterilization ${ }^{9,10}$. Due to the adverse effects heat treatments may incur undesirable changes in foods, such as changes in nutritionalvalues, developing burning flavour, and unpleasant taste, studies have attempted to identify non- thermal alternatives ${ }^{11,12}$. Methods being studied include gamma irradiation with ethylene dioxide, aqueous sanitizers (trisodium phosphate, chlorine, and hydrogen peroxide), hypochlorite solutions, microwave, pulse electromagnetic field and ultrasound ${ }^{11,12,13,14}$.

Although these methods are effective, undesirable qualities have been associated with it's use. Gaseous ethylene oxide, for example, has been banned in many countries due to the negative effects on health and environment. Satisfactory results had not been observed from the sole use of aqueous sanitizers, while use of chlorine may lead to form trihalomethane, a health hazardous chemical ${ }^{11}$. The successful use of heat is dependant on the correct 
combination of time and temperature (T\&T), both of which can be linked to the loss of nutrients and flavor along with changes to the functional property of the food ${ }^{15}$. Various remaining residues and environment pollution are a cause for concern while using chemicals ${ }^{2}$.

Negative effects associated with methods previously used for decontamination of foods are analysed. Conventional methods such as heat, although effective, economical and easily available, has been reported to produce undesirable effects on food such as loss of taste and nutrition ${ }^{6,16}$. Often, when used in canned or bottled foods, the slow cooling and heating rates can negatively affect product quality ${ }^{17}$. Hot water or hot air treatments also have to be monitored to ensure the proper temperature and time is being used and it can often be a lengthy process ${ }^{18}$. Methods such as gamma irradiation, high energy electrons, hydrostatic pressure, UV treatments, ozonation, power ultrasound and pulsed light are expensive and may affect the quality of the food ${ }^{6}$. Additionally, methods such as gamma radiation and high energy electron beams have been associated with adverse consumer perceptions and adverse effects on foods as a result of treatment ${ }^{19}$. Fumigation with ethylene oxide, although efficient, has been linked with the development of cancer, therefore its use is banned in European Union countries ${ }^{20}$.

The search for safe, environmentally friendly methods, which have no effect on food quality has become a top priority in maintaining food safety. Ideally, effective treatments should harmless, stable, no toxic residue and uniformly applied throughout the food processing ${ }^{21}$. Recent studies have focused on the application ofpressure in the decontamination of foods. Pressure used as a method of decontamination can produce high quality foods with increased shelf-lifewithout adverse effect on the food ${ }^{22}$. They have not been linked to changes in physical features and they have been reported to work in the same way in all shapes and sizes of foods, as they are spread uniformly ${ }^{16}$. Both High-Pressure Processing (HPP) ${ }^{23}$ and Cold Plasma Technology (CPT) are being studied in the decontamination of foods ${ }^{16,21,24}$. The current review asses the use of both these techniques in maintaining food safety and decontamination of foods.

\section{High Pressure Processing.}

High pressure processing (HPP) has emerged as a commercially viable food manufacturing tool that satisfies consumers' demand for mildly processed, convenient, fresh-tasting foods with minimal to no preservatives ${ }^{24}$. High Pressure Processing (HPP) can inactivate the cells of the pathogens and organisms responsible for spoilage regardless of the temperature without making changes to the texture, color or flavor ${ }^{17,25,26}$. Its uses mainly revolved around ceramics, composite material, plastics and carbon graphite $^{27}$. It was first applied to food in 1899 when it was used to delay microbial spoilage in milk ${ }^{27}$. It functions by interrupting cellular mechanisms involved in reproduction, by interfering with
DNA replication, and survival as well as damaging bacterial membranes and denaturing enzymes, particularly those associated with efflux of protons ${ }^{16,17}$. Equipment involved in HPP include a pressure vessel, pumps generating high hydrostatic pressure or intensifiers ${ }^{16}$. Its success depends on certain factors such as pressure of water, temperature used during the treatment, and the properties and state of the food and the microorganisms found on $\mathrm{it}^{27}$. A schematic diagram of HPP is shown in Fig. ${ }^{28}$.

Gram negative bacteria and rods have shown more sensitivity to pressure, with lethality increasing as time and pressure used in the treatment increases. ${ }^{25}$. Some viruses have also been inactivated with high pressure, for example those which are protein- DNA viruses (bacteriophages), whereas lipid coated viruses were unaffected by $\mathrm{HPP}^{27}$.

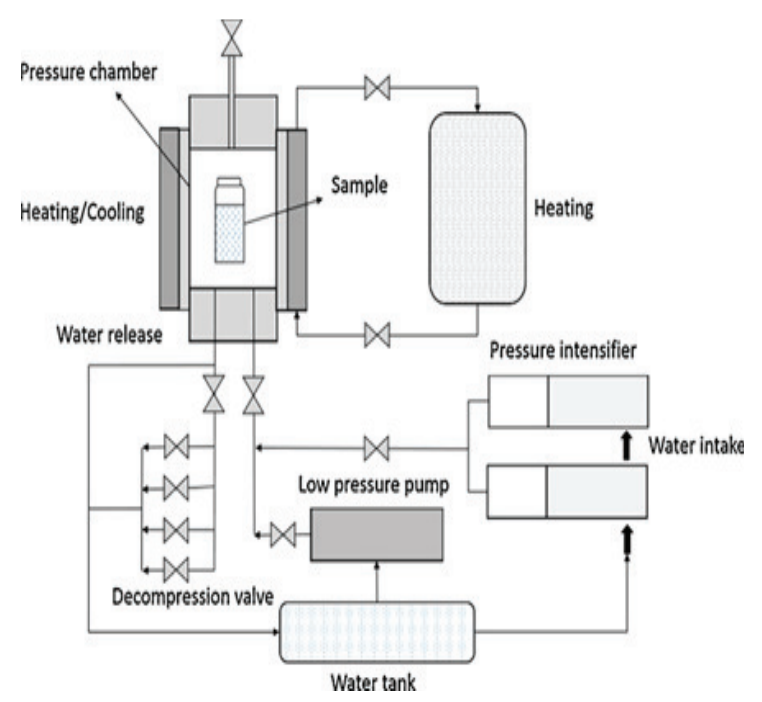

Fig. 1. Schematic diagram of high pressure processing ${ }^{28}$

It is currently used by AvomexInc in USA for Avocado paste and by GrupoJumex in Mexico for juices ${ }^{16}$. Studies by Ponce $e t a l$. $(1998)^{26}$ have also demonstrated its effectiveness in eliminating Listeria spp. in liquid eggs, especially when combined with the addition of Nisin. A study conducted by Jin and Harper (1996), as mentioned in Capellaset al. $(2000)^{25}$, found HPP to be highly effective in inactivating organisms in cheese as well as flavor development.Hite(1899) ${ }^{29}$ investigated theapplicationofhigh pressure in preserving milk, and later Hite, et al. $(1914)^{30}$ applied this technique to preserve fruits and vegetables.After about eighty years, Japan re-discovered the applicationof high-pressureinfood processing, and within three years two Japanese companies to launch products, which were processed using this technology. The high pressure for its efficacy to inactivate microorganisms and spoilage catalyzing enzymes has encouraged Japanese and American food companies to introduce high pressure processed food sinthemarket ${ }^{31,32}$. The ûrst high pressure processed foods were introduced to the Japanese market in 1990 by Meidi-ya, who have been marketing a line of jams, jellies, and sauces packaged and processed without application of heat ${ }^{33}$. Other 
products include fruit preparations, fruit juices, rice cakes, and raw squid in Japan; fruit juices, especially apple and orange juice, in France and Portugal; and guacamole and oysters in the $\mathrm{USA}^{34}$.In addition to food preservation, high-pressure treatment can result novel structure and texture in developing new food products $^{35}$.

\section{Disadvantagesof HPP}

HPP has been highly effective indifferent categories of foods, showing no damage or change to low- molecular weight food compounds, which includes flavoring agents, pigments and vitamins ${ }^{22}$. Additionally, it can reach all parts of the food in a uniform manner no matter the size or shape of the food, without causing damage to proteins or biologically active compounds ${ }^{16,27}$. Studies have also suggested that foods treated and those without treatment are nearly indistinguishable, when comparing sensory characteristics ${ }^{16}$. Its benefits have also been observed in oysters ${ }^{16}$. The use of HPP can also reduce the safety risks to production workers, increase the shelf-life of refrigerated foods and reduce the risk of consuming raw foods ${ }^{16}$. An important benefit of HPP is its low energy output and the ability of small molecules to be stable during the treatment ${ }^{27}$.

Studies have seen reductions of more than 6-log in cheese, with pressure set to 400-500 MPa for 15 minutes, but the same studies have found HPP to have no effect on spores at $1000 \mathrm{MPa}^{25}$. Spores sensitivity was observed in studies which combine HPP with high temperature ${ }^{17}$. Use of HPP requires a large investment, but satisfactory application of the product can eventually overcome the costs ${ }^{16,27}$. Still there are some limitations of HPP, Table 1 summarizes some key advantages and limitations of high pressure applications in the food industry ${ }^{24}$.

\section{Mode of HPP action on microorganisms}

The effects of HPP on microorganisms in/on meat and meat products are dependent on many characteristics of microorganism and food product.HPP causes various changes in the cell membrane, the cell wall, ribosomes and enzymes that are responsible for inactivation of microorganisms, of which cell membrane damage is the main cause of cell death, due to interfering on permeability, osmotic pressure and transport systems $^{36,37,38,39}$. Moreover, high pressure directly leads to denaturation and agglomeration of proteins and subsequent inactivation of the enzymes ${ }^{40}$.

Single- and/or multi-cell parasites consist of complex structure, which is affected severely by lower pressure ranging from 200 to $300 \mathrm{MPa}^{38,41}$. Moulds and yeasts exhibit moderate HPP resistance, with the exception of certain ascospores of heat resistant moulds (Neosartorya, Talaromyces, Byssochlamys),

Table 1. Unique advantages and limitations of high pressure food processing ${ }^{24}$

\begin{tabular}{|c|c|c|}
\hline Description & Advantage & Limitations \\
\hline Hydrostatic pressure & $\begin{array}{l}\text { Rapid, quasi-instantaneous uniform } \\
\text { distribution throughout the sample }\end{array}$ & $\begin{array}{l}\text { throughout the sample batch or } \\
\text { semicontinuous operation }\end{array}$ \\
\hline Thermal distribution & $\begin{array}{l}\text { Minimal or reduced thermal } \\
\text { exposure Instant temperature } \\
\text { increase and subsequent cooling } \\
\text { upon depressurization }\end{array}$ & $\begin{array}{l}\text { Instant temperature increase and } \\
\text { subsequent cooling upon depressurization, } \\
\text { Preheating step } \\
\text { for pressure-assisted thermal processing } \\
\text { (PATP). Thermal nonuniformity during } \\
\text { PATP }\end{array}$ \\
\hline Physical compression & $\begin{array}{l}\text { Suitable for high moisture-content } \\
\text { foods }\end{array}$ & $\begin{array}{l}\text { Not suitable for products containing } \\
\text { dissimilar compressibility materials such as } \\
\text { marshmallows }\end{array}$ \\
\hline Product handling & $\begin{array}{l}\text { Suitable for both liquid and } \\
\text { pumpable foods }\end{array}$ & Throughput limited due to batch operation \\
\hline Process time & $\begin{array}{l}\text { Independent of product shape and } \\
\text { siz }\end{array}$ & \\
\hline Functionality & $\begin{array}{l}\text { Opportunity for novel product } \\
\text { formulation Distinct products } \\
\text { through pressure effects such as } \\
\text { protein denaturation, carbohydrate } \\
\text { gelatinization, and fat crystallization }\end{array}$ & \\
\hline Reaction rate & $\begin{array}{l}\text { Within some pressure-thermal } \\
\text { boundary conditions, pressure } \\
\text { accelerates microbial inactivation }\end{array}$ & $\begin{array}{l}\text { Variable efficacy in enzyme inactivation; } \\
\text { pressure alone cannot inactivate bacterial } \\
\text { spores }\end{array}$ \\
\hline Consumer acceptance & $\begin{array}{l}\text { Consumer acceptance as a physical } \\
\text { process }\end{array}$ & $\begin{array}{l}\text { Higher processing costs and batch } \\
\text { operations are barriers for commodity } \\
\text { product processing }\end{array}$ \\
\hline
\end{tabular}


which are able to tolerate pressures higher than $600 \mathrm{MPa}^{27,42}$. The bacterial vegetative cells are more resistant than moulds and yeasts for their thicker and stronger cell wall. Gram positive bacteria are more resistant than the Gram negative bacteria, and cocci are more resistant than rods ${ }^{36,43}$. Bacterial cells in the exponential phase are more sensitive to pressure compared to the cells in the stationary phase $\mathrm{e}^{44,45,46}$. An experiment carried out by Liang Zhaoa, et al. (2017) ${ }^{28}$ on inactivation of $E$. coli and Staphylococcus aureus in PBS (pH 7.0) treated by $\mathrm{CO} 2(0 \%$ and 20\%)-HPP (300 MPa/3 min) (Table 2) and his finding supported the findings of McClementset al., (2001) ${ }^{44}$, Manas and Mackey (2004) $)^{45}$ and Hayman et al. $(2007)^{46}$.

Bacterialspores cannot be destroyed by application of high pressure alone, as treatment intensity at usual processing temperatures is inadequate. Furthermore, pressure-assisted thermal processing (PATP) is a method used for food sterilization that combines high pressure $(>600 \mathrm{MPa})$ and temperatures above $60^{\circ} \mathrm{C}$. The advantages of PATP include a lower processing temperature and/or shorter exposure of the product to high temperature, compared to conventional sterilization $^{38,47,48,49}$.

Viruses exhibit diverse resistance to HPP, but can be inactivated by high pressure. Prions are destroyed only by using extremely high pressure $(\geq 700 \mathrm{MPa}$ ) concurrently with high temperature $\left(\geq 60^{\circ} \mathrm{C}\right)^{37,50}$ found that after application of $800 \mathrm{MPa}(5 \mathrm{~min}$, $80^{\circ} \mathrm{C}$ ), infectivity of prions significantly decreased.

There are some important applications of HPP are listed in Table $3^{24}$

Table 2. Effect of growth phase on inactivation of E. coli and S. aureus in PBS (pH 7.0) treated by $\mathrm{CO}_{2}(0 \%$ and $20 \%)$-HPP (300 $\mathrm{MPa} / 3 \mathrm{~min})^{28}$

\begin{tabular}{|c|c|c|c|}
\hline Microorganism & $\mathrm{CO}_{2}$ ratio, by volume & Mid-exponential phase Lg N/ $\mathrm{N}_{0}$ & Stationary phase Lg N/ $\mathrm{N}_{0}$ \\
\hline E. coli & $0 \%$ & “6.555 $\pm 0.191 \mathrm{a}$ & “ $4.480 \pm 0.300 \mathrm{~b}$ \\
\hline & $20 \%$ & “7.496 $\pm 0.562 \mathrm{a}$ & “5.126 $\pm 0.053 b$ \\
\hline S. aureus & $\begin{array}{c}0 \% \\
20 \%\end{array}$ & $\begin{array}{l}\text { "3.026 } \pm 0.984 a \\
\text { "5 } 352 \pm 0.279 a\end{array}$ & $\begin{array}{l}\text { "1.962 } \pm 0.125 b \\
\text { "2 } 2693 \pm 0.035 b\end{array}$ \\
\hline
\end{tabular}

All data were the means $\pm \mathrm{SD}, \mathrm{n}=3$.Values with diûerent letters within one row are signiûcantly different $(\mathrm{P}<0.05)$.

Table 3. Selected scientiûc and commercial milestones in high pressure food processing applications ${ }^{24}$

\begin{tabular}{ll}
\hline Year & Application \\
1881 & Conversion of starch into sugar \\
1897 & $\begin{array}{l}\text { Inversion of cane sugar } \\
\end{array}$ \\
1899 & Starch sacchariûcation \\
1900 & Experiments on milk preservation 1899 \\
1909 & Experiments on compressibility \\
1912 & Water phase diagram \\
1914 & Coagulation of albumen \\
1918 & Pressure effects on bacteria \\
1920 & Continuous manufacture of phenols \\
1923 & Experiments on thermal conductivity \\
1943 & Mutarotation of glucose \\
1969 & Biological reaction rates \\
1970 & Decaffeinating coffee via supercritical ûuid extraction \\
1980 & Beef protein quality \\
1990 & Meidi-Ya Food Co. launched high pressure-treated products in Japan \\
1995 & Thermodynamic properties of water under pressure, NIST/ASME Steam database \\
1997 & Pressure-treated Gucagmole by Avomex (now Fresherized Foods) \\
1998 & Spain introduced pressure-treated sliced cooked ham \\
2002 & Hormel introduced pressure-treated deli meat products in the US market \\
2005 & Cited as one of the best innovations in food processing \\
2009 & FDA issued no objection to an industry petition for PATP (research sponsored by Army-Industry consortium) \\
2012 & Introduction of pressure-treated juices \\
2013 & Development of pressure-ohmic-thermal sterilization \\
\hline
\end{tabular}

Abbreviations: ASME, American Society of Mechanical

Engineers; FDA, US Food and Drug Administration; NIST,

National Institute of Standards and Technology; PATP,

pressure-assisted thermal processing. 


\section{Cold Plasma Treatment}

Plasma is defined as ionized gas consisting of photons, ions, radicals and free electrons in combination with excited

$s$ at a neutral charge ${ }^{22}$. Cold Plasma Treatment (CPT) is a method which relies on the discharge of plasma coupled with a combination of gas, ions, electrons and radicals; all working together to inactivate the organisms ${ }^{9,51}$. There are two types of plasma; non- thermal plasma (NTP), which functions at lower pressure and thermal plasma, which functions at higher pressure ${ }^{6}$. These methods were mostly limited to medical equipment sterilization, only recently gaining interest in food decontamination ${ }^{9}$. In addition to that, there is no need for use of chemicals or high temperature, minimising or removing any associated adverse effects on the food treated ${ }^{22}$.CPT relies on cold plasma, making it effective on bacteria, bacterial endospores, molds and yeasts ${ }^{19}$.Plasma can interact with the biological material allowing it to work against a variety of organisms including spores and viruses, without damaging the host, in this case the food itself ${ }^{6}$.

Oxygen used at low pressure was effectively able to break down lipids, proteins and DNA of cellsimplying the viability of both the machine and gas as a trustworthy sterilizing mechanism. They prevent the passage of biomolecules across the cell membrane by affecting the fatty acids and the lipid bilayereventually leading to denaturation, rupture and leakage ${ }^{6}$.

In food industry, food-borne pathogens and spoilage microorganisms lead to public health risks and economic impact $^{52}$. Microbial contamination of fruits and vegetables is another major problem. Truly, all categories of food undergo varying degrees of biological (spoilage and food borne pathogens and their enzymes), chemical and physical deterioration after harvest and during food storage, resulting undesirable change in nutritional value, safety and aesthetic appeal like colour, texture and flavour. The need for fast distribution of perishable fresh produces from farm to fork needs effective sanitation techniques to reduce microbial loads without any negative effects on product quality.
Effective and easy-to-apply inactivation approaches for fruits and vegetables have taken on a high priority. Various treatments have been using to decontaminate unwanted microorganisms which include UV treatment, steam, heat sterilization and irradiation. However, UV radiation is ineffective due to lack of penetration. Steaming is effective for decontamination, but has limitations and irradiated foods are unpopular in some countries and japan is one of them. Conventional thermal methods of food sterilization are unsuitable for fruits and vegetables, because heating causes inevitable changes of color, smell, flavor, and a loss of nutritional value. For the past two decades, research in food science has largely focused on non-thermal technologies such as high pressure (discussed earlier), non-thermal plasma, pulsed electric field, ultrasound, pulsed light, and ozone processing technologies to preserve food while limiting the impact of processing on nutritional and sensory quality, and without compromising safety ${ }^{53}$.

Non thermal plasma is a new discipline in food processing applied for decontamination of fruits and fresh produces. It is considered to be the fourth state of matter in the world ${ }^{54}$. As stated earlier plasma is an ionized gas that consists of a huge number of various species such as electrons, photons, positive and negative ions, free radicals, gas atoms and molecules in the ground or excited state.Plasma can be generated at low temperature typically by applying a voltage to a gas. Theelectric field generated from the applied voltage can accelerate any free electrons in the gas.

Accelerated electrons collide with gas atoms to excite or ionize them. Ionization of gas atoms release more electrons; this cascaded reaction can generate a rich abundance of highly reactive chemical species which are capable of inactivating a wide range of microorganisms including food borne pathogens and spoilage organisms.

The generation of plasma in wide range of temperature and pressure is carried out by means of coupling energy to gaseous medium. Fig. 2 depicts the generation of plasma from different states of material (Fig2.a) ${ }^{23}$ and the plasma able to inactivate microbes (Fig2 b).

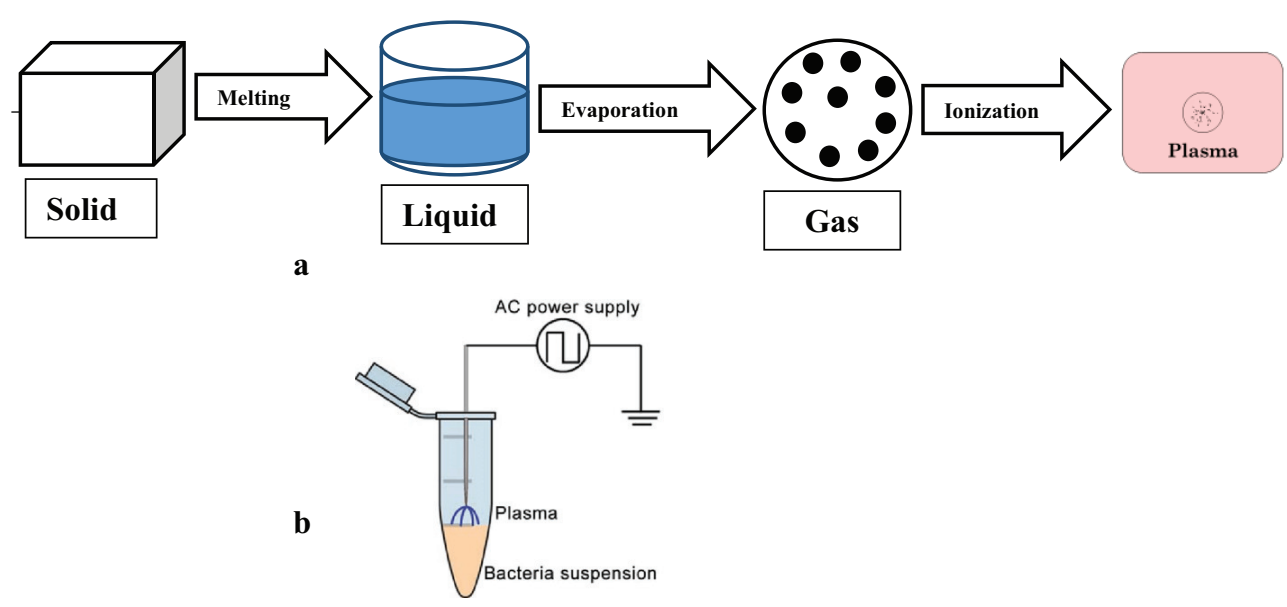

Fig.2. (a) Generation of plasma from different states of material ${ }^{23}$ and (b) application in inactivation of microorganisms 
Escherichia coli, Salmonella typhimurium, Staphylococcus aureus, Listeria monocytogenesBacillus cereus and Enterococcus faecalis are common food-borne pathogens capable of causing severe diseases and in some cases even death ${ }^{55}$. Raw agricultural produces have frequently been implicated in disease outbreaks. CPT able to ensure the microbiological safety of a food,and minimizes changes to its sensory, nutritional, and functional properties ${ }^{45}$.
The pathogen inactivation effects of cold plasma potentially offer a treatment step for fresh produce to reduce the microbial load without adversely affecting the nutritional and other key characteristics. Recent important ûndings on plasma based inactivation of microorganisms have been summarized in Table $4^{6}$

Cold Plasma Technology: a tool for microbial inactivation Plasma generation leads to production of reactive spices which exert

Table 4. Recent ûndings in the area of nonthermal plasma for the inactivation of microorganisms and spores ${ }^{6}$

\begin{tabular}{|c|c|c|c|c|}
\hline Microorganism & $\begin{array}{l}\text { Plasma } \\
\text { conditions }\end{array}$ & $\begin{array}{l}\text { Treatment } \\
\text { surface/ } \\
\text { medium }\end{array}$ & Salient results & reference \\
\hline $\begin{array}{l}\text { Escnerichia coli, } \\
\text { Staphylococcusaureus }\end{array}$ & $\begin{array}{l}\text { Atmospheric } \\
\text { plasma corona } \\
\text { discharge, with } \\
\text { high-voltage }(20 \\
\mathrm{kV}) \text { DC power } \\
\text { supply }\end{array}$ & On agar plates & $\begin{array}{l}\mathrm{pH} \text { changes from } \\
\text { alkaline to acid, upon } \\
\text { plasma application to } \\
\text { bacteria in water; does } \\
\text { not play a predominant } \\
\text { role in cell death. }\end{array}$ & $\begin{array}{l}\text { Korachi, et } \\
\text { al. }(2010)^{56}\end{array}$ \\
\hline $\begin{array}{l}\text { E. coli type } 1, \text { Saccharomyces } \\
\text { cerevisiae, } \\
\text { Gluconobacterliquefaciens, } \\
\text { Listeria monocytogenes }\end{array}$ & $\begin{array}{l}\text { Cold atmospheric } \\
\text { plasma plume } \\
\text { generated by an } \\
\mathrm{AC} \text { voltage of } 8 \\
\mathrm{kV} \text { at } 30 \mathrm{kHz}\end{array}$ & $\begin{array}{l}\text { Inoculated } \\
\text { membrane } \\
\text { filters and } \\
\text { inoculated fruit } \\
\text { surfaces }\end{array}$ & $\begin{array}{l}\text { Inactivation efficiency } \\
\text { was markedly reduced } \\
\text { for microbes on the cut } \\
\text { surfaces than on filters } \\
\text { due to the migration of } \\
\text { microbes from the } \\
\text { exterior of the fruit tissue } \\
\text { to its interior and not } \\
\text { quenching of reactive } \\
\text { plasma species. }\end{array}$ & $\begin{array}{l}\text { Perni, et al. } \\
(2008)^{57}\end{array}$ \\
\hline $\begin{array}{l}\text { E. coli O157:H7 Salmonella } \\
\text { Stanley }\end{array}$ & $\begin{array}{l}\text { Gliding Arc } \\
\text { plasma }\end{array}$ & $\begin{array}{l}\text { On agar plates } \\
\text { and inoculated } \\
\text { onto surfaces } \\
\text { of Golden } \\
\text { Delicious } \\
\text { apples }\end{array}$ & $\begin{array}{l}\text { Bacterial inactivation } \\
\text { was shown to be a } \\
\text { function of low rate and } \\
\text { duration of exposure. }\end{array}$ & $\begin{array}{l}\text { Niemira and Sites } \\
(2008)^{58}\end{array}$ \\
\hline $\begin{array}{l}\text { Aspergillus parasiticus and } \\
\text { Aflatoxins }\end{array}$ & $\begin{array}{l}\text { Air gases and } \\
\text { SF6 plasma using } \\
\text { total applied } \\
\text { power of } \\
\text { approximately } \\
300 \mathrm{~W}\end{array}$ & $\begin{array}{l}\text { Hazelnuts, } \\
\text { Peanuts and } \\
\text { Pistachio nuts }\end{array}$ & $\begin{array}{l}\text { SF6 plasma reduces } 5 \text { log } \\
\text { fungal population for the } \\
\text { same duration as air } \\
\text { gases plasma. Air gases } \\
\text { plasma treatment reduces } \\
50 \% \text { of total aflatoxins, } \\
\text { while SF6 plasma } \\
\text { treatment reduces only a } \\
20 \% \text { for } 20 \text {-min. }\end{array}$ & $\begin{array}{l}\text { Basaran, et } \\
\text { al. }(2008)^{59}\end{array}$ \\
\hline $\begin{array}{l}\text { E. coli, } \\
\text { S. cerevisiaePantoeaagglomerans, } \\
\text { Gluconacetobacterliquefaciens }\end{array}$ & $\begin{array}{l}\text { Cold atmospheric } \\
\text { plasma generated } \\
\text { by an AC voltage } \\
\text { (variable } 12 \mathrm{kV} \\
\text { and } 16 \mathrm{kV} \text { ) }\end{array}$ & $\begin{array}{l}\text { Pericarps of } \\
\text { mangoes and } \\
\text { melons }\end{array}$ & $\begin{array}{l}\text { S. cerevisiaeis resistant } \\
\text { organisms. Increased } \\
\text { voltage was more } \\
\text { efficient reactive plasma } \\
\text { species (oxygen atoms), } \\
\text { which was attributed for } \\
\text { better inactivation. }\end{array}$ & $\begin{array}{l}\text { Perni, et } \\
\text { al. }(2008)^{57}\end{array}$ \\
\hline $\begin{array}{l}\text { E. coli } \mathrm{O} 157: \mathrm{H} 7, \text { Salmonella } \mathrm{sp} . \\
\text { L.monocytogenes }\end{array}$ & $\begin{array}{l}\text { One atmosphere } \\
\text { uniform glow } \\
\text { discharge plasma } \\
\text { operated at } 9-\mathrm{kV} \\
\text { power and } 6-\mathrm{kHz} \\
\text { frequency }\end{array}$ & $\begin{array}{l}\text { Apples, } \\
\text { cantaloupe and } \\
\text { lettuce }\end{array}$ & $\begin{array}{l}\text { Inactivation was } \\
\text { observed in all the cases. } \\
\text { Extent of log reduction } \\
\text { varied with the } \\
\text { organisms. }\end{array}$ & $\begin{array}{l}\text { Critzeret al. } \\
(2007)^{60}\end{array}$ \\
\hline $\begin{array}{l}\text { Biofilms produced by } \\
\text { Chromobacteriumviolaceum }\end{array}$ & $\begin{array}{l}\text { RF high-pressure } \\
\text { cold plasma jet } \\
\text { using Atomflo } \\
250 \text { reactor with } \\
100 \mathrm{~W} \text { RF power } \\
\text { supply using He } \\
\text { and N2 gas }\end{array}$ & $\begin{array}{l}\text { Biofilms } \\
\text { produced in } \\
\text { 96-well } \\
\text { polystyrene } \\
\text { microplates }\end{array}$ & $\begin{array}{l}\text { A } 10 \text { min plasma } \\
\text { treatment was able to kill } \\
\text { almost } 100 \% \text { of the cells. } \\
\text { A complex, biphasic } \\
\text { model of inactivation } \\
\text { was observed. }\end{array}$ & $\begin{array}{l}\text { Abramzon, et al. } \\
(2006)^{61}\end{array}$ \\
\hline
\end{tabular}


oxidative effects on the outer surface of microbial cells. Nitrogen and oxygen gas plasma are good sources of reactive oxygenbased and nitrogen-based spices such as $\mathrm{O}_{\text {, }} \mathrm{O}_{2}, \mathrm{O}_{3}, \mathrm{OH}, \mathrm{NO}$., $\mathrm{NO}_{2}$. These act on the doubled bond of unsaturated fatty acids of membrane cell, thereby disturbing the transport of bimolecular across it. The oxidation of the lipids, amino acids and nucleic acids makes cells and spores unable to active and lead to microbial death or injury. In addition to reactive spices, UV photons can modify the DNA of the microorganisms and interrupt cell replication ${ }^{62}$.

As shown in Fig.3schematic diagram of continuous plasma system in that required gas supply, power supply are available. Sample can pass through the conveyer belt and above it there is different plasma jets which treats the samples and directly go to packaging area for safe packaging. This technique may help in large scale treatment.

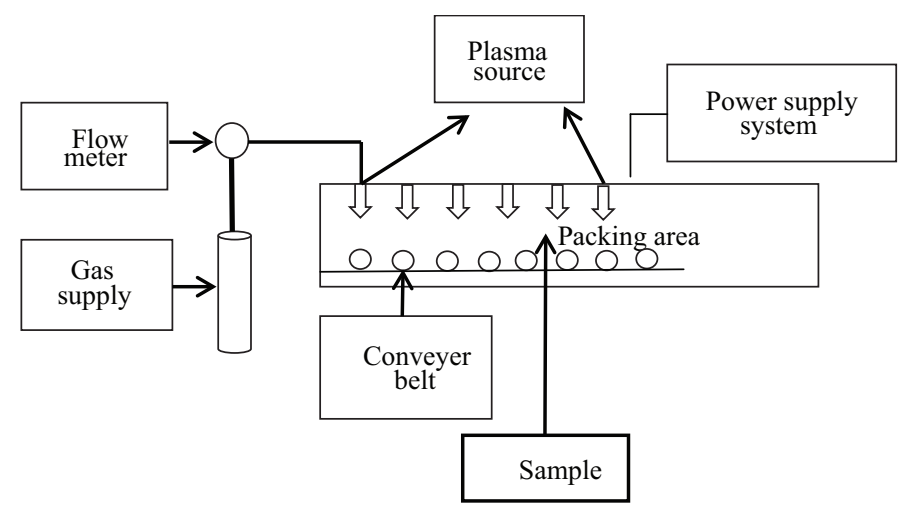

Fig 3. Schematic diagram of continuous plasma system for decontamination of food ${ }^{24}$

\section{Advantage and Disadvantages}

The key advantages of non-thermal plasma technologies are relatively simple and inexpensive design, requiring short processing times, absence of toxicity, and lack of residue formation. The use of cold plasmas at ambient pressure in air and/or other operating gases and gas mixtures, resulting inactivation of microorganisms such as bacteria, bacterial spores, fungi, biofilm and decomposition of pesticide ${ }^{57,63}$ in heat sensitive foods. The basic mechanism of producing cold plasma is to apply high voltage pulse in a flowing gas (Fig.2 b). To produce cold atmospheric pressure plasma, different research groups have used different input parameters and based on the mode of plasma ignition, it is categorized as Resistive Barrier Discharges (RBD), Dielectric barrier discharges (DBD), Corona Plasma Discharges (CPD), Cascaded Dielectric Barrier Discharge (CDBD), and the Atmospheric Pressure Plasma Jet (APPJ) ${ }^{23}$.

Recent developments have allowed this treatment to be carried out without vacuum equipment and at atmospheric pressure reducing the cost and ease of use significantly ${ }^{18}$. Plasma has the added benefit of deep penetration, even through cracks and crevices, no matter what the shape is, therefore they can be more useful than other methods which only rely on surface decontamination ${ }^{6}$.Various studies have used LPP on seed disinfection with high degree of success, with some showing increase in germination rate after treatment was completed ${ }^{18}$. Studies with plasma were also able to prove that treatment had no effect on seed viability or the qualities of food such as wheat and beans ${ }^{6}$. It is a quick non- chemical and non- thermal method that can be used without leaving any toxic residue making it safe while being easy to operate ${ }^{18}$. Studies by Hertwiget al., (2014) ${ }^{19}$ have been successful in reducing the microbial load of spices using LPP. The same study also observed no color change after treatment of spices such as black pepper. A point to consider is the effectiveness of the method on high lipid content food, such as meats, which may be affected by the oxidation and possibly lead to the formation of hydroxyl acids, keto acids, short chain fatty acids and aldehydes ${ }^{6}$.

A comparative analysis between the treatment process such as heat treatment and low-pressure plasma treatment on the growth of bacteria and fungi has been demonstrated in the Table 5 . Bacterial and Fungal log reduction of plasma treatments were greater than that of heat treatment. Cold Plasma Treatment was able to reduce the bacterial and fungal growth up to $3.43 \log \mathrm{cfu} /$ $\mathrm{g}$ and $2.75 \mathrm{cfu} / \mathrm{g}$ respectively. This suggests Cold Plasma Treatment is an effective alternative to the conventional heat methods.

Table 5. Comparison of the effects of both (heat treatment and low pressure plasma treatment) treatments ${ }^{9}$

\begin{tabular}{|c|c|c|c|c|}
\hline \multirow[t]{3}{*}{ Name of the Samples } & \multicolumn{4}{|c|}{ Total Log reduction } \\
\hline & \multicolumn{2}{|c|}{ Heat Treatment } & \multicolumn{2}{|c|}{ Cold plasma treatment } \\
\hline & Bacterial & Fungal & Bacterial & Fungal \\
\hline Coriander Powder & 0.53 & 0.27 & 5.40 & 3.63 \\
\hline Chili Powder & 1.58 & 0.35 & 5.75 & 3.97 \\
\hline Poppy Seeds & 0.62 & 0.95 & 4.11 & 3.56 \\
\hline Ginger Powder & 0.15 & 0.56 & 3.56 & 5.91 \\
\hline Cumin Powder & 0.12 & 1.04 & 2.37 & 2.15 \\
\hline Turmeric Powder & 1.35 & 3.55 & 5.18 & 4.76 \\
\hline Pine Nuts & 2.04 & 0.60 & 3.34 & 2.60 \\
\hline
\end{tabular}


The design versatility, non-thermal, economical and environmentally friendly nature of cold plasma offers unique advantages over traditional processing technologies. However, cold plasma processing is still in its nascent form and needs further research to reach its potential.

\section{Conclusion}

Although humans rely on food to survive, foods can contribute to developing bacterial and fungal infections, serving as vehicles for transmission ${ }^{64}$. The consumption of foiled foods have been linked with serious diseases, including cancer ${ }^{65}$. For this reason, studies focusing on the development or improvement of techniques which decontaminate foods are important for maintaining the health and safety ${ }^{9}$. Various techniques exist, in both commercial and laboratory settings, all displaying several advantages and disadvantages associated with use. Current study reviewed methods relying on the use of pressure for the decontamination of foods, which included High Pressure Processing (HPP) and Cold Plasma treatment (CPT).

Both these methods are safe and reliable as they do not require the use of chemicals or preservatives. They have the added benefit of leaving no change to the taste, appearance or texture of the foods ${ }^{21,22}$. Both HPP and CPT can spread and work on the entire food sample, regardless of shape and sizeCPT $6,16,27$. These methods serve as an alternative to some methods which were previously uses such as gamma irradiation, high energy electrons, hydrostatic pressure, UV treatments, ozonation. All these methods are linked with various effects on health of consumer and the environment ${ }^{6}$. Methods such as heat have also been linked to adverse effects on the taste, nutrition and appearance of the food $^{16,17}$. Further detailed studies are still required on changes to nutritional content of the food post treatment.

The methods discussed in the current review are able to decontaminate the foods, while not subjecting the foods to the effects of the former techniques. The current review encourages the use of these two pressure methods in the large scale decontamination of foods, as a stand alone method or used in combination with others.

\section{References:}

1. Samapundo S, Devlieghere F, Geeraerd AH, Meulenaer BD, Van Impe JF and Debevere J. 2007. Food Microbiol. 24:517-529.

2. Farkas J. 1998. Microbiological safety of irradiated foods. Int. J Food Microbiol. 9: 1-15.

3. Buck JW, Walcott R and Beuchat LR. 2003. Recent Trends in Microbiological Safety of Fruits and Vegetables. Online. Plant Management Network. Progress doi:10.1094/PHP-2003-0121-01-RV

4. Caradamone C, Aleo A, Mammina C, Oliveri G and Di Noto AM. 2015. Assesment of the microbiological quality of fresh produce on sale in Sicily, Italy: preliminary results. J Biol Res- Thessaloniki. 22(3). DOI 10.1186/ s40709-015-0026-3, available at: https://www.academia.edu , Assessment_of_the_microbiological_quality_

5. Alam MS, Feroz F, Rahman H, Das KK and Noor R. 2015. Microbiological contamination sources of freshly cultivated vegetables. Nut. Food Sci. 44(4): 646-658.
6. Misra NN,Tiwari BK, Raghavarao KSMS and Cullen PJ. 2011. Nonthermal Plasma Inactivation of Food-Borne Pathogens. Food Eng. Rev.3: 159-170.

7. Abadias M, Usall J, Anguera M, Solsona C and Viñas I. 2008. Microbiological quality of fresh, minimally- processes fruit and vegetables and sprouts from retail establishments. Int. J. Food Microbiol. 123: 121129.

8. Yoon JY and Kim B. 2012. Lab-On-Chip Pathogen Sensors for food Safety. Sensors 12:10713-10741.

9. Feroz F, Shimizu H, Nishioka T, Mori M and Sakagami Y. 2016. Bacterial and fungal counts of dried and semi-dried foods collected from Dhaka, Bangladesh and their reduction methods. Biocontrol Sci. 21(4):243-251.

10. Lurie S. 1998. Postharvest heat treatments. Postharvest Biol Technol. 14: $257-269$

11. Birmpa A, Vantarakis A, Paparrodopoulos, Whyte P and Lyng J. 2014. Efficacy of three light technologies for reducing microbial populations in Liquid suspensions. Biomed. Research Int. 2014: 1-9.

12. Eliasson L, Isaksson S, Lovenklev M and Ahrné. 2015. A comparative study of infrared and microwave heatinf for microbial decontamination of paprika powder. Front Microbiol. 6:1071.

13. Juri ML, Ito H, Watanabe H and Tamura N. 1986. Distribution of Microorganisms in Spices and Their Decontamination by Gammairradiation. Agri. Biol. Chem. 50(2): 347-355.

14. Chemat F, Zill-e-Humaand Khan MK. 2011. Applications of ultrasound in food technology: processing, preservation and extraction. Ultrason. Sonochem. 18: 813-835.

15. Piyasena P, Dussault C, Koutchma T, Ramaswamy HS and Awuah GB. 2003. Radio frequency heating of foods: principles, applications and related properties: a review. Crit. Rev. Food Sci. Nutr. 43(6): 587-606.

16. Torres JA and Velazques G. 2005. Commercial opportunities and research challenges in the high pressure processing of foods. J. Food Eng. 67: 95-112.

17. Matser AM, Krebber B, van den Berg RW and Bartels PV. 2004. Advantages of high pressure sterilisation on quality of food products. Food Sci. Technol. 15: 79-85.

18. Nishioka T, Takai Y, Kaeardanu M, Okada K, Tanimoto H, Misawa T and Kusakari S. 2014. Seed Disinfection Effect of Atmospheric Pressure Plasma and Low Pressure Plasma on Rhizoctoniasolani. Biocont Sci. 19(2): 99-102.

19. Hertwig C, Reineke K, Ehlbeck J, Erdogdu B, Rauh C and Schluter O. 2014. Impact of remote plasma treatment on natural microbial load and quality parameters of selected herbs and spices. J Food Eng. 167: 12-17.

20. Hertwig C, Reineke K, Ehlbeck J, Knorr D and Schluter O. 2015. Decontamination of whole black pepper using different cold atmospheric pressure plasma application. Food Control. 55: 221-229.

21. Selcuka M, Oksuzb L and Basarana P. 2008. Decontamination of grains and legumes infected with Aspergillus spp. and Penicillum spp. by cold plasma. Biores Technol. 99(11): 5102-5109.

22. Butz P, García A F, Lindauer R, Dieterich S, Bognár A and Tauscher B. 2003. Influence of ultra high pressure procession on fruit and vegetables products. J Food Microbiol. 56: 233-236.

23. Hetal KB, Prasad RV, Joshi DC and Sagarika N. 2018. Non-Thermal plasma system for decontamination of fruits, vegetables and spices: A review. Int J Chem Studies, 6(2): 619-627.

24. Balasubramaniam VM, Sergio I, Inez-Monteagudo M and Gupta R. 2015. Principles and Application of High Pressure-Based Technologies in the Food Industry. Annu. Rev. Food Sci. Technol. 6:19.1-19.

25. Capellas M, Mor-Mur M, Gervilla R, Yuste J and Guamis B. 2000. Effect of high pressure combined with mild heat or nisin on inoculated bacteria and mesophiles of goat's milk fresh cheese. Food Microbiol. 17: 633641 . 
26. Ponce E, Pla R, Sendra E, Guamis B and Mor-Mur M. 1998. Combined effect of nisin and high hydro-static pressure on destruction of listeria innocua and Escherichia coli in liquid whole egg. Int. J. Food Microbiol. 43: 15-19.

27. Smelt JPPM. 1998. Recent advances in the microbiology of high pressure processing. Food Sci Technol. 5: 152-158.

28. Zhaoa L, Qinb X, Wanga Y, Lingd J, Shib W, Pang S and Liaoa X. 2017. $\mathrm{CO}_{2}$-assisted high pressure processing on inactivation of Escherichia coli and Staphylococcus aureus. J Co Utiliz. 22:53-62.

29. Hite BH.1899. The effect of pressure in the preservation of milk.Washington, Va. University, Agri Expt. Station, Bulletin, 58: 15-35.

30. Hite BH, Giddings NJ and Weakly, CE. 1914. The effects of pressure on certain microorganisms encountered in the preservation of fruits and vegetables. Washington, Va. University, Agri. Expt. Station, Bulletin, 146: $1-67$.

31. Mermelstein NH. 1997. High pressure processing reaches the US market. Food Technol. 51:95-96.

32. Hendrickx M, Ludikhuyze L, Broeck Van den I and Weemaes C. 1998. Effect of high pressure on enzymes related to food quality. Trends in Food Sci. Technol. 9:197-203.

33. Thakur BR and Nelson PE.1998. Highpressureprocessingandpreservation of foods. Food Rev Int. 14(4): 427-447.

34. Hugas M, Garriga M, and Monfort JM. 2002.Newmildtechnologiesinmeat processing: high pressure as a model technology. Meat Sci. 62(3): 359- 371 .

35. Hayashi R. 1990. Application of high pressure to processing and preservation: philosophy and development. In Engineering and Food. (edsSpiess, W.E.L., and Schubert, H.). Elsevier Applied Science, London. UK. 815-826.

36. Patterson M F. 2005. Microbiology of pressure-treated foods. J App Microbiol. 98 (6): 1400-1409.

37. Campus M. 2010. High pressure processing of meat, meat products and seafood. Food Eng Rev. 2(4): 256-273.

38. Simonin H, Duranton F. and de Lamballerie M. 2012. New insights into the high-pressure processing of meat and meat products. Comprehen. Rev. Food Sci. Food Safety, 11: 285-306.

39. FDA (Food and Drug Administration). 2014. Food Section: Kinetics of Microbial Inactivation for Alternative Food Processing Technologies High Pressure Processing. Washington DC. US Dept. of Health and Human Services, Public Health Service, Food and Drug Administration. United States Department of Agriculture. Available at: http://www.fda.gov/Food/ Food Science Research/Safe Practices for Food Processes/ucm 101456.htm

40. Bajovic B, Bolumar T and Heinz V. 2012. Quality considerations with high pressure processing of fresh and value added meat products. Meat Sci. 92(3): 280-289

41. Yuste J, Capellas M, Fung D Y C and Mor-Mur M. 2001. High pressure processing for food safety and preservation: a review. Journal of Rapid Methods and Automationin Microbiology, 9(1): 1-10.

42. Chapman B, Winley E, Fong ASW, Hocking AD, Stewart CM and Buckle KA. 2007. Ascospore inactivation and germination by high-pressure processing is aûected by ascospore age. Inno Food Sci. Emer Technol. 8(4): $531-4$.

43. Murchie LW, Cruz-Romero M, Kerry J P, Linton M, Patterson MF, Smiddy M and Kelly AL. 2005. High pressure processing of shellûsh: a review of microbiological and other quality aspects. Inno Food Sci Emerging Technols. 6: 257-270.

44. McClements J M, Patterson MFand Linton M. 2001. The eûect of growth stage and growth temperature on high hydrostatic pressure inactivation of some psychrotrophic bacteria in milk. J Food Protect. 64: 514-522.

45. Manas P and Mackey BM. 2004. Morphological and physiological changes induced by high hydrostatic pressure in exponential- and stationary-phase cells of Escherichia coli: relationship with cell death. App. En. Microbiol., 70(3): 1545-1554.
46. Hayman MM, Anantheswaran RC and Knabel SJ. 2007. The eûects of growth temperature and growth phase on the inactivation of Listeria monocytogenes in whole milk subject to high pressure processing. Int $J$ Food Microbiol. 10: 220-226.

47. Cheftel JC. 1995. Review: high-pressure, microbial inactivation and food preservation. Food Sci. TechnolInt. 1: 75-90.

48. Bermúdez-Aguirre D and Barbosa-Cánovas G. 2011. An update on high hydrostatic pressure, from the laboratory to industrial applications. Food Engi Rev. 3(1): 44-61.

49. Mújica-Paz H, Valdez-Fragoso A, Tonello Samson C, Welti-Chane SJ. and Torres, JA. 2011. High-pressure processing technologies for the pasteurization and sterilization of foods. Food and Biopro Technol. 4 (6): 969-85.

50. Heindl P, Garcia AF, Butz P, Trierweiler B, Voigt H, Pfaû E and Tausher B. 2008. High pressure/temperature treatments to inactivate highly infectious prion subpopulations. Inno. Food Sci. Emerging Technol. 9: 290-297.

51. Von Keudell A, Awakowicz P, Benedikt J, Raballan V and Yanguas- Gil et al. 2010. Inactivation of bacteria and biomolecules by low pressure plasma discharges. Plasma Process Polym. 7: 327-352.

52. Ragni L, Berardinelli A, Vannini L, Montanari C, Sirri F and Guerzoni ME. 2010. Non-thermal atmospheric gas plasma device for surface decontamination of shell eggs. J. Food Eng. 100(1): 125- 32.

53. Grzegorzewski F, Rohn S, Quade A, Schröder K, Ehlbeck J and Schlüter O. 2010. Reaction chemistry of 1,4benzopyronederivates in nonequilibrium lowtemperature plasmas. Plasma Processes Polym. 7(6): 466473.

54. Laroussi M, Tendero C, Lu X, Alla S and Hynes WL. 2006. Inactivation of bacteria by the plasma pencil. Plasma Processes Polym. 3: 470-473.

55. Yun H, Kim B, Jung S, Kruk ZA, Kim DB, Choe W and Jo C. 2010. Inactivation of Listeria monocytogenes inoculated on disposable plastic tray, aluminum foil, and paper cup by atmospheric pressure plasma. Food Control. 21(8): 1182-1186.

56. Korachi M, Gurol C and Aslan N. 2010. Atmospheric plasma discharge sterilization effects on whole cell fatty acid proûles of Escherichia coli and Staphylococcus aureus. J. Electrostat 68(6): 508-512.

57. Perni S, Liu DW, Shama G and Kong MG. 2008. Cold atmospheric plasma decontamination of the pericarps of fruit. J Food Protect. 71(2): 302-308.

58. Niemira BA and Sites J. 2008. Cold plasma inactivates Salmonella Stanley and Escherichia coli O157: H7 inoculated on golden delicious apples. $J$ Food Protect. 71(7):1357-1365.

59. Basarana P, BasaranAN and Oksuz L. 2008. Elimination of Aspergillus parasiticus from nut surface with low pressure cold plasma (LPCP) treatment. Food Microbiol. 25: 626-632.

60. Critzer FJ, Kelly Wintenberg K, South SJ and Golden A. 2007. Atmospheric plasma inactivation of foodborne pathogens on fresh produce surfaces. J Food Protect. 70: 2290-2296.

61. Abramzon N, Joaquin JC, Bray J and Brelles-Marino G. 2006. Bioûlm destruction by RF high-pressure cold plasma jet. Plasma Sci IEEE Trans. 34(4): 1304-1309.

62. Boudam M, Saoudi B, Popovici C and Gherardi NFM. 2006. Bacterial spore inactivation by atmospheric pressure plasmas in the presence or absence of UV photons asobtained with the same gas mixture. $J$ Phys $D$ Appl Phys. 39: 3494.

63. Zhu WC, Wang BR, Xi HL and Pu YK. 2010. Decontamination of VX surrogatemalathion by atmospheric pressure radiofrequency plasma jet, Plasma Chem. Plasma Process. 30: 381-389.

64. Hasibur R, Farahnaaz F, Sajjad MA, Kamal KD and Rashed N. 2016. Demonstration of the source of microbial contamination of freshly cultivated cabbage, cauliflower, potato and squash collected from rural farms of Bangladesh. Int Food Res J. 23(3): 1289-1295.

65. Hashem M and Alamri S. 2010. Contamination of common spices in Saudi Arabia markets with potential mycotoxin producing fungi. Saudi J. Biol. Sci. 14: 167-175. 